\title{
Regímenes de movilidad y domesticación del espacio
}

\section{Mobility regimes and domestication of space}

\author{
Ignacio MENDIOLA \\ Universidad del País Vasco \\ ignacio.mendiola@ehu.es
}

Recibido: 16.02 .2012

Aprobado definitivamente: 02.10 .2012

\begin{abstract}
RESUMEN
Este artículo pretende establecer una línea argumental entre movilidad, espacio y biopolítica. La movilidad será analizada en tanto que práctica geográfica que traza conexiones entre espacios alterando en mayor o menor medida el ordenamiento de los espacios que son puestos en relación y de las subjetividades que los habitan. El objetivo es sugerir un escenario analítico desde el que pensar posteriormente, en su especificidad empírica, prácticas concretas de movilidad; un escenario que, a modo de acercamiento conceptual progresivo, dibuja los lindes de un recorrido que, en sus hitos fundamentales, se constituye, en primer lugar, en torno a una ontología biopolítica de la habitabilidad que cuando es puesta en conexión con la movilidad demanda analizar el modo en que se rearticulan los hábitos al iniciarse el viaje-desplazamiento y el modo en que se resuelve la hospitalidad-hostilidad en la zona de contacto; en segundo lugar, subraya la existencia en la modernidad de un ethos que promueve la domesticación de los espacios y de la movilidad; por último, se incide en la reconfiguración de ese ethos en la modernidad tardía desde la articulación de unas gubernamentalizaciones que activan regímenes de movilidad trenzados alrededor de lo neoliberalneocolonial-securitario y que se plasma de formas diversas en las figuras más relevantes de la movilidad actual como son los migrantes y los turistas.
\end{abstract}

Palabras clave: Biopolítica, movilidad, gubernamentalidad, espacio

\begin{abstract}
This paper aims to trace a connection between mobility, space and biopolitics. Mobility will be analysed as a geographical practice that brings together spaces altering their orderings and the subjects that inhabit them. An analytical scenery will be outlined in order to think later on the specificity of concrete practices of mobility. A scenery that is developed in a progressive way attending, first, to a biopolitical ontology of habitability that, related to mobility, demands an analysis of the way habits are reconfigured when travel-displacement begins and of the way hospitality-hostility is arranged in the contact zone; second, it will be argued that modernity develops an ethos through which domestication of spaces and mobility is accomplished; and lastly, it will be analysed the way that ethos of modernity is reconfigured through gubernmentalities that link neoliberal-neocolonial-security dimensions and that becomes expressed in those key figures of present mobility: tourists and migrants.
\end{abstract}

KeYwords: Biopolitics, mobility, gubernmentality, space.

\section{SUMARIO}

1.Introducción. 2.Habitando la movilidad. 3.La modernidad y la domesticación del espacio. 4.Regímenes de movilidad en la modernidad tardía. 5.Conclusión. 


\section{INTRODUCCIÓN}

Imbuido de un imaginario moderno que ensalzaba las múltiples posibilidades que la tecnología ofrecía a la vida y al conocimiento, Julio Verne se atrevía ya a afirmar en su Viaje de la tierra a la luna que "la palabra distancia envuelve una idea relativa que acabará por reducirse a cero". Siglo y medio después, a menudo se nos dice que la actual movilidad, convertida en uno de los conceptos centrales desde los que se piensa el mundo que habitamos, viene a corroborar la primacía del tiempo sobre el espacio, de la velocidad sobre las limitaciones que antes imponía el tener que recorrer esos espacios que ahora pueden ser comprimidos por las potencialidades que nos ofrecen los dispositivos tecnocientíficos (la comunicación instantánea por Internet o la antes inimaginable disminución en los tiempos del viaje). La velocidad vendría así a consumar la utopía de Verne, permitiéndonos decir que vivimos en una suerte de "universo software" en donde "el espacio ya no limita la acción ni sus efectos, y cuenta muy poco o nada en absoluto" (Bauman, 2006: 126). La movilidad se abrirá, desde ahí, tanto al despliegue acelerado que impregna las formas de vida como a la incertidumbre ontológica que depara la vivencia misma de la movilidad.

Este es el escenario: la creciente importancia de la movilidad en una parte considerable de las ciencias sociales tiene lugar en el marco de todo un entramado metafórico que, gravitando en torno a la fluidificación de lo social, confiere más importancia al cambio y a la velocidad que a los espacios en los que acontece la movilidad. La añeja dicotomización de lo social en términos de espacio-tiempo parece reproducirse una vez más a costa de un espacio que queda como trasfondo difuminado de lo que realmente importa, que no es otra cosa que una urdimbre de transformaciones sociales insertas en una vorágine en la que a duras penas se atisba a comprender su funcionamiento, sumiendo así a los sujetos que la padecen en una incertidumbre insoslayable que amenaza con quebrar las cotidianas formas de hacer y pensar en torno a las cuales se tejían los modos de estar en el mundo. Habitar la movilidad es habitar la incertidumbre; la otrora certidumbre asociada a un espacio reconocible, con sus modos de vivir más o menos establecidos y consolidados, parece quedar atrás cuando el espacio se ve atravesado por todo un entramado de sujetos y objetos encaramados a la movilidad, cuando al espacio reconocible le so- brevuela la amenaza de quedar convertido en un nolugar, en un espacio de tránsito, de ir y venir, espacio (re)creado para movernos pero no para estar.

La metaforología articulada en torno a lo líquido y lo fluido, de la cual Bauman es su gran valedor, parece quedar en última instancia atrapada por el binomio movilidad-incertidumbre de un modo tan exacerbado que incluso puede llegar a afirmarse que la fluidificación de la modernidad, al socavar lo que antes se presentaba como sólido, ha acabado por cambiar "la condición humana de modo radical" (Bauman, 2006: 14). El presente incierto fagocita al pasado y al futuro dejándonos un campo experiencial carente de marcos de referencia. La metáfora del viaje sin rumbo viene aquí de nuevo como signo de nuestros tiempos, como el rostro límpido en el que ver la movilidad que habitamos. Los viajeros, todos nosotros, descubrimos "con horror que la cabina del piloto está vacía y que no hay manera de extraer de la misteriosa caja negra rotulada "piloto automático" ninguna información acerca del destino del avión, del lugar donde aterrizará, de la persona que elegirá el aeropuerto y de si existen reglas que los pasajeros pueden cumplir para contribuir a la seguridad del aterrizaje" (Bauman, 2006: 65).

Pero cabe preguntarse si verdaderamente esta imagen, a pesar del éxito sociológico que ha tenido, no resulta en última instancia más impactante que efectiva puesto que al elaborarse desde un trasfondo epistemológico que prioriza lo fluido sobre lo sólido, el tiempo sobre el espacio, la incertidumbre sobre la certidumbre, parece olvidar que el movimiento no se puede dar sino en el espacio, a través del espacio, recomponiendo sus formas: la movilidad, en la específica topología del espacio que rearticula, pone en tránsito personas, cosas, tecnologías, imágenes, ideas etc. recreando así una alteración, de mayor o menor calado, en las relaciones que ya existen y en los posicionamientos de lo que es puesto en relación. E, igualmente, parece olvidar que la movilidadincertidumbre está permeada por un ordenamiento político-económico-jurídico, por todo un entramado de relaciones de poder a través de las cuales se recomponen esas relaciones y posicionamientos así como las subjetividades ahí presentes. Así las cosas, la geografía de la movilidad y el ordenamiento (biopolítico) de los espacios parecen quedar ubicados en un segundo plano. Y será precisamente ese doble pilar el que guía y da forma a esta reflexión: por una 
parte, un intento por despojar a la movilidad de esa ideación utópica propia del viejo imaginario moderno (que en su ensalzamiento del progreso no dejaba de elogiar ideas concomitantes como la velocidad y el cambio) para atender a las prácticas concretas de movilidad en lo que tienen de formas de habitar y dar forma a los espacios; por otra, un acercamiento al modo en que se estructura la movilidad bajo la premisa de que ésta responde en sus formas a modos de ordenar el espacio y las relaciones entre los espacios, con lo que cabría hablar, en clave biopolítica, de un ordenamiento gubernamental de la movilidad (Foucault, 2006), de la composición de regímenes de movilidad desde los que se rearticulan formas de vida. La movilidad muestra así una doble faz que se abre desde su gubernamentalidad (ordenamiento de los espacios) hasta sus plasmaciones específicas (formas de habitar).

En este momento preliminar conviene recordar lo que ya sugería Foucault en su seminal artículo sobre las heterotopías: "La época actual sería más bien quizá la época del espacio. Estamos en la época de lo simultáneo, en la época de la yuxtaposición, en la época de lo próximo y lo lejano, de lo contiguo, de lo disperso. Estamos en un momento en que el mundo se experimenta, creo, menos como una gran vía que se despliega a través de los tiempos que como una red que enlaza puntos y que entrecruza su madeja" (Foucault, 1999: 431). No se trata, en modo alguno, de intentar rivalizar sobre cómo hay que articular jerárquicamente la dicotomía espaciotiempo cuanto de tener presente que los polos de esa falsa dicotomía atraviesan, según el modo en que quedan concebidos y estructurados, la práctica de la movilidad y que la movilidad es, antes que nada, un desplazamiento por el espacio, un asunto geográfico, en la que cobra una importancia crucial el modo en que quedan entrelazados los espacios, las conexiones y fronteras que se trazan. Y es, por ello, que suscribimos, como punto de partida, como anclaje epistemológico de lo que después habrá de venir, la apreciación de Deleuze y Guattari: "Los viajes no se distinguen ni por la cualidad objetiva de los lugares ni por la cantidad mensurable del movimiento -ni por algo que estaría únicamente en el espíritu- sino por el modo de espacialización, por la manera de estar en el espacio, de relacionarse con el espacio" (1998: 490).
Pensar la movilidad es pensar el hacerse y deshacerse del espacio, el modo en que se practica, las formas en las que se ordena, las conexiones que se trazan, teniendo presente que todo espacio, como más adelante volverá a enfatizarse, lleva la huella de otros espacios, y que la adjudicación de lugares, el modo en que las cosas y las personas se posicionan responde a procesos sociohistóricos que torna falaz la presunción de que hay un supuesto espacio propio que en rigor nos correspondería habitar: "La formación de lugares -históricos, geográficos, culturales- es siempre derivado y no originario, el resultado de una negociación, de un acuerdo, de una relación de fuerzas o de un enfrentamiento violento, nunca un producto espontáneo de la naturaleza o el espíritu" (Pardo, 1998: 178); habitamos, en su concreción específica, lugares y la relación entre lugares, las conexiones y las fronteras, la movilidad y la inmovilidad. Consideración esta que exige asumir una doble premisa que, aún cuando no sea objeto de un desarrollo específico, hay que explicitar al menos sucintamente en esta introducción con el objeto de clarificar los lindes del territorio analítico que sugerimos. Evitar, en un plano epistemológico, la cosificación del movimiento al margen de su anclaje espacial porque lo social no sólo se da en el espacio sino que acontece, como ya sugirió Simmel, de forma espacializada; y evitar igualmente, en un plano simbólico, un ensalzamiento del movimiento en detrimento de otras formas de estar en el mundo que se asocian a lo inmovil, como si éstas fueran rescoldos de formas de vivir que no han sabido adaptarse a los tiempos (rápidos) de la modernidad y que acaso sólo merecen elogio cuando se proyectan sobre culturas exóticas: el indígena que está ahí porque vive ahí, porque ese es su espacio (pero de nuestro vivir se exige disponibilidad para el cambio, una maleabilidad que implica también la aceptación acrítica de la movilidad).

No cabe duda de que el escenario que abre la movilidad es de una amplitud difícilmente abarcable en toda su extensión ya que lo pueblan una miríada de sujetos, objetos, imágenes o flujos informacionales portando cada uno de ellos sus propias características, con lo que no cabría hablar de una única racionalidad propia de nuestras "sociedades móviles" cuanto de racionalidades y plasmaciones específicas que evacuan la posibilidad misma de un discurso con cualquier atisbo de sesgo teleológico 
y homogeneizante. Desde esta premisa, la reflexión que aquí se expone pretende articular un escenario desde el que pensar la relación entre espacio, movilidad y biopolítica, estableciendo como eje central de análisis la práctica del viaje-desplazamiento entre espacios: el viaje-desplazamiento funciona así como nexo entre el espacio y la biopolítica, como vínculo que conexiona la relación entre espacios, como campo de análisis en donde desbrozar las relaciones de poder que permean los tránsitos. Un escenario este que no pretende ahondar en un desplazamiento concreto cuanto sugerir un entramado conceptual para pensar esa relación espacio-movilidad-biopolítica apuntando, asimismo, que esa relación está mediada por la presencia de un ethos multiforme que acompaña a la (tardo)modernidad y que se cifra en un proceso de domesticación de los espacios y de la movilidad misma. Si bien la idea del viaje guiará la argumentación, lo que se intentará poner de manifiesto como hilo conductor de la reflexión es que el viaje está sumido en unos regímenes de movilidad gubernamentalizados que tienden a la domesticación y codificación del movimiento.

Para ello, el artículo se construye en tres momentos diferenciados que atienden, en primer lugar, a trazar los lindes de una red conceptual básica en donde el desplazamiento irrumpe como un ejercicio de rearticulación del modo en que se habitan los espacios operado en una "zona de contacto" que oscila entre la hospitalidad y la hostilidad; en segundo lugar, se sugerirá una lectura de la modernidad como dispositivo de movilización que promueve la domesticación de los espacios y de la movilidad; por último, y partiendo de la centralidad que tienen las figuras del migrante y del turista en los regímenes de movilidad desplegados en esta modernidad tardía, se analizará el modo en que dichos regímenes reproducen de formas diversas la mencionada domesticación del espacio y la movilidad.

\section{HABITANDO LA MOVILIDAD}

La superación de una visión cosificada del espacio que lo circunscribe a una materialidad desprovista de la huella que deja el modo en que se ejercita el vivir y de una visión psicologizada que lo encierra en una ideación que omite la propia especificidad del espacio en su materialidad constituyente, nos permite acercarnos a una lectura topológica del espacio en la que subrayar su performatividad y relacionalidad. El espacio, más que estar dado, se da, adquiere formas cambiantes en el modo en que se (re)construye, retomando a Lefebvre (1998), mediante un entramado de representaciones (a cerca de lo que debe ser el espacio), construcciones (ordenamientos del espacio) y prácticas (el ejercicio mismo del espacio en tanto que formas de habitarlo); triada analítica desde la que acercarnos al modo en que se producen y vivencian los espacios. Decir que el espacio se da, es sugerir ya que el espacio está dándose, que no deja de darse, de acontecer y que ello no es sino la huella de un cierto inacabamiento estructural que pone de manifiesto la dinamicidad del espacio para (en el modo en que es representado-construido-practicado) recomponer relaciones de diverso signo, reconfigurar sus ordenamientos, resituar a los habitantes de los espacios. Hablar del espacio es así alejarse de cualquier atisbo de suspensión temporal para adentrase en los modos de espaciar, de crear espaciamientos, reordenamientos del hábitat que habitamos y aquí, sobra decirlo, nada es neutral, las relaciones de poder atraviesan estos procesos dejando su huella tanto en la producción semiótico-material del hábitat como en la subjetividad del habitante (Massey, 2005).

Cabe sugerir entonces -desde este planteamiento que está en la base de lo que hemos dado en llamar ontología biopolítica de la habitabilidad (Mendiola, 2009, 2012) y que ahora exponemos sucintamente-, que las formas de vida pueden ser leídas como formas de ocupar y practicar los espacios y, asimismo, como corolario de esta afirmación, que el estudio de la biopolítica comienza a revelarse como un ejercicio de geopolítica que indaga en la espacialización de las formas de vida. El ejercicio de espacializar la biopolítica o de biopolitizar el espacio deviene así un ejercicio bifronte que mira, por una parte, al ordenamiento del hábitat mediante todo un entramado de racionalidades y tecnologías en los que se condensa el modo en que ha de ser concebido y construido el espacio y, por otra, a los procesos de subjetivación encarnados, a las formas de vida que irrumpen en esos espacios. Hay ciertamente algo de este carácter bifronte cuando Foucault resalta la importancia en el ámbito de las relaciones de poder de una lógica gubernamental que no se inscribe (sólo) sobre el cuerpo de los sujetos cuanto sobre el espacio que éstos 
habitan y su campo de actuación. El ejercicio de poder, dirá Foucault, "es un conjunto de acciones sobre posibles acciones que opera en el campo de lo potencial, donde se inscribe en el comportamiento de los sujetos que actúan: incita, induce, facilita o dificulta; amplia o restringe, hace más o menos probable; en el límite, constriñe o prohíbe de manera absoluta; de cualquier modo siempre es una manera de actuar sobre un sujeto que actúa o sobre sujetos actuantes en virtud de su capacidad de acción" (2001: 431). La gubernamentalidad (Foucault, 2006) designará todo un entramado de formas de hacer y pensar que tiene por objeto, sobre la base de la economía política y de una serie de dispositivos de seguridad, el ordenamiento de la población, su gobierno, de un modo tal que lo que la distingue de anteriores dispositivos de poder (soberanos y disciplinarios) es que es un actuar mayormente concernido con gestionar las posibilidades de actuación de las personas, con lo que adquiere una gran relevancia el ejercicio de ordenar el espacio que se habita, el modo en que ha de ser habitado, en un ejercicio que alude tanto a la conducción (flujos, conexiones, tránsitos, fronteras) como a la conducta (hábitos, formas de pensar, de hacer, de estar). Desde este prisma, la historia de la movilidad podría ser leída como una historia de las distintas formas de gubernamentalidad que la subyacen porque el sujeto irrumpe siempre en un espacio gubernamentalizado que produce formas de vida, habita una movilidad que le precede, incorpora unos hábitos que producen subjetividad.

Sin embargo, la reactualización del predominio del tiempo sobre el espacio que ha traído consigo la fluidificación de lo social también venía acompañada de una invidualización de los sujetos que se manifiesta en una reflexividad acentuada para poder hacer frente a la precariedad e incertidumbre que se desprende de unos contextos sociales que no reproducen ya pautas estables de comportamiento: la difuminación del espacio encumbra la reflexividad del sujeto como las dos caras de un mismo proceso indisoluble. Y es, por ello, que la necesidad que aquí se reivindica de espacializar lo social, y en paralelo la biopolítica y la movilidad, actúa a contracorriente de ese sujeto reflexivo que encara la incertidumbre sin saber con certeza a dónde ir o qué hacer. Si con algo nos confrontan las formas de vida espacializadas, más allá de las múltiples formas que pudieran ser adoptadas, es que el sujeto es siempre un habitante de hábitats que le preceden, un habitante que encarna, en su piel y en su discurso, hábitos que se abren a formas de hacer, pensar y sentir. Habitamos lo que nos precede, los hábitos, los hábitats, y eso deja una huella imborrable en el habitante que sólo puede hacer, decir y pensar desde lo que le hace, le piensa y le dice. Habitamos un "murmullo anónimo" (Foucault), un rumor impersonal que se posa en los hábitos que habitamos, un entramado semiótico-material que hace habitantes. Habitamos, en consecuencia, una heterogeneidad que impide el cierre del sujeto sobre sí mismo, un cruce de caminos que se amalgama en el discurso que enuncia el sujeto empírico que habla, un enjambre de espacios que se agolpa en el espacio concreto que se habita en lo local.

Que el habitante siempre porte una trama de hábitos y hábitats que no ha hecho pero que le permiten hacer (un hacer sobre y desde lo que le hace) en modo alguno nos aboca a una lectura determinista de la subjetividad, a considerar al sujeto como una huella pasiva de lo que le precede (Butler, 2006); tan sólo lo resitúa y lo ubica en la potencia fundante de la cotidianidad, allí donde tiene lugar la repetición del hábito, allí donde el sujeto puede problematizar (no sólo para activar líneas de fuga, sino también para ejercer codificaciones de otro signo) aquello que le constituye como sujeto, que le sujeta a su subjetividad. Las formas de vida devienen así formas de habitar que reproducen una cotidianidad susceptible de ser problematizada en el momento mismo en el que se constituye, de nuevo, lo cotidiano, esto es, en el momento de la repetición que inaugura cada vez, otra vez, el hábito que se dice, se hace y se piensa. Nos alejamos del sujeto reflexivo, encaramado a los imaginarios de la construcción más o menos racional de lo social, para acercarnos a un sujeto que habita hábitats y hábitos mediante una repetición que no es sinónimo de pasividad (Ingold, 2000); un sujeto que conoce, piensa y actúa desde los espacios en los que está situado (Haraway), un sujeto que se abre al sentido desde el modo en que siente el mundo en su corporalidad (Le Breton, 1995; Nancy, 2010). Y también hoy y aquí, en este contexto que se lee desde una incertidumbre exacerbada (como si otras épocas, tal y como nos recuerda Benjamin, no hubiesen tenido ya esa misma sensación de quiebra radical del mundo), seguimos estando situados y seguimos sintiendo el mundo: tan sólo nos situamos de otras formas y sentimos de otros modos. 
Será así en torno a este sujeto que se reconfigura sociohistóricamente desde los espacios que habita desde donde se articula una ontología biopolítica de la habitabilidad que enhebra espacio y subjetividad atendiendo a las relaciones de poder existentes y a las temporalidades que permean los hábitats y los hábitos: espacios, subjetividades, relaciones de poder y temporalidades conforman los ejes en torno a los cuales se inicia una reflexión de referencias mutuas que tiene por objeto indagar en las formas de habitar y en los desplazamientos que se desencadenan desde los hábitats. Ejes que, como se observa, están enunciados en plural porque todos ellos están atravesados por lo heterogéneo, por relaciones de diverso signo que se solapan, porque no cabe hablar en rigor de tiempo o espacio sino de tiempos y espacios (Adam, 1998; Serres, 1995), porque el poder es siempre una urdimbre de relaciones de poder que codifican y descodifican (Foucault, 1995; Deleuze y Guattari, 1998), porque el sujeto ha perdido ya el rostro unívoco que nunca tuvo y se recompone con otros discursos y sujetos en un existir que es siempre un coexistir plural y tensionado.

En este contexto cabe ya acercarse a la movilidad como una práctica siempre situada, espacializada, que a modo de un pliegue multiforme traza conexiones entre espacios; la movilidad nos introduce en una topología del espacio que abre una "zona de contacto" (Pratt, 1992) entre el que está y el que llega, un ámbito de relación que puede operarse de muy diversos modos pero lo que queremos resaltar en este momento es el entrelazamiento espacial que lleva consigo la movilidad y, en un sentido más profundo, conectando con lo que anteriormente se ha dicho, la idea de que todo espacio encierra una intrahistoria de movilidades y conexiones que han incidido en el ordenamiento semiótico-material en torno al cual traza su diferencialidad. Las apreciaciones de Clifford cobran en este sentido una importancia seminal: "Si nos replanteamos la cultura y su ciencia, la antropología, en términos de viaje, queda puesta en tela de juicio la inclinación orgánica, naturalizadora de la cultura vista como un cuerpo dotado de raíces que se desarrolla, vive, muere, etc. Y al tiempo se hacen más claramente visibles construcciones históricas muy discutidas, lugares para el desplazamiento, la interferencia y la interacción” (...) ¿Por qué no considerar el modo en que una cultura es el espacio de viaje para otros, el modo en que los es- pacios son atravesados desde fuera, el modo en que el centro de un grupo es la periferia de otro? (1995: 55). No sólo que se establezcan prácticas de movilidad entre espacios sino que el espacio mismo es ya la huella de las movilidades que lo han atravesado, de los flujos de personas, información o materias, que lo han ido conformando. La cultura como viaje, como espacio hendido por otros espacios, horadado por la movilidad. En las acertadas palabras de Pardo: "En el principio no era el lugar, en el principio era el traslado, con lo que el traslado tiene de pérdida de la propia esencia, de la propia identidad, del propio espíritu y de la propia cultura, con lo que tiene de desnaturalización y de falsificación" (1998: 184; subrayado en el original).

Así las cosas, la práctica efectiva de la movilidad emerge como una realidad multidimensional que en su propia especificidad sería susceptible de ser analizada atendiendo a las geografías que compone (los espacios elegidos para desplazarse, las rutas que se toman para conectar dos o más espacios distantes), a los tiempos de la movilidad (la velocidad con la que se desplazan los sujetos u objetos, la duración de la movilidad, los ritmos que se emplean), a los relatos que acompañan el desplazamiento (narrativas en torno a lo que se espera del propio viaje, narrativas que simbolizan y confieren un sentido al espacio al que se va, pero también narrativas acerca de cómo se definen a los habitantes de otros espacios y cómo esos mismos habitantes conciben a las personas que llegan), a las relaciones de poder que afectan al modo en que se practica la movilidad (el modo en que los espacios se ven transformados en sus ordenamientos internos por las prácticas de movilidad que les atraviesan, las alteraciones que todo ello pudiera desatar en los habitantes de esos espacios, la imposición misma del desplazamiento para determinados sujetos o las violencias que se pueden desatar en el propio trayecto) y a los sujetos-objetos que pueblan la movilidad (sujetos categorizados como turistas, desplazados, migrantes, aventureros, exploradores, misioneros, comerciantes etc. pero también objetos de diverso signo como dispositivos sociotécnicos, materias primas, productos manufacturados, cosechas, flujos de información). Geografías, temporalidades y relaciones de poder conforman, en sus mutuas remisiones a la subjetividad que viaja y a la subjetividad que recibe al viajero, las vías de entrada para desbrozar el modo en que 
acontece cada movilidad y las consecuencias que ésta depara.

La movilidad muestra aquí sus múltiples caras, las distintas facetas que están presentes cuando tiene lugar; pero quizás cabría, en esta aproximación que confiere un papel central a la práctica del viaje-desplazamiento, destacar dos dimensiones que, en cierto sentido, vienen a condensar los distintos elementos enumerados en el párrafo anterior, al tiempo que nos permite conectar de un modo más preciso la movilidad con ya mencionada ontología biopolítica de la habitabilidad. La primera designa la tensión, más o menos explícita, que se desata cuando el desplazamiento mismo acontece, cuando la partida (ese irse que lleva consigo un partir, una escisión) se inicia. Podemos aquí hacer referencia a dos ejemplos literarios en donde queda recogido de un modo nítido la idea a transmitir. Por una parte, la apreciación de Claudio Magris en su magnífico libro de viajes El Danubio: "El viaje es la fidelidad del sedentario, que afirma en todas partes sus hábitos y sus raíces e intenta engañar, con la movilidad en el espacio, la erosión del tiempo, para repetir siempre las cosas y los gestos familiares: sentarse a la mesa, charlar, amar, dormir" (2007: 44). Por otra parte, la reflexión que recoge el protagonista de la novela de Juan José Saer, El entenado, cuando se refiere a las idas y venidas que realizaban los indios que le tenían prisionero: "Era como si volviesen no al propio hogar, sino al del acontecer. Ese lugar era, para ellos, la casa del mundo. Si algo podía existir, no podía hacerlo fuera de él. En realidad, afirmar que ese lugar era la casa del mundo es, de mi parte, un error, porque ese lugar y el mundo eran, para ellos, una y la misma cosa. Dondequiera que fuesen, lo llevaban dentro. Ellos mismos eran ese lugar. En él nacían y morían, sembraban y trabajaban, y, cuando salían de pesca o de caza, era ahí a donde traían lo que recogían. Sus expediciones, eran como una prolongación elástica del lugar en que vivían; o, como lo llevaban dentro, era como si ese lugar se desplazase con ellos a cada desplazamiento".

En estas reflexiones, el viaje denota la "fidelidad del sedentario", la "prolongación elástica del lugar", esto es, el intento de que en la partida, todo aquello que se revela crucial para quien se pone en movimiento, su coraza de hábitos -eso que lúcidamente Juan José Saer había definido como la "contingencia salvadora"-, quede protegida en el transcurso del viaje de tal forma que cuando uno se desplaza lleve consigo lo que le constituye como sujeto, como habitante de unos hábitats que ahora quedan atrás; pero anida aquí una tensión insoslayable que no siempre adquiere una fácil resolución y que no es otra que la que se cierne sobre el hecho de que los hábitos que hay que mantener tenían su sentido en el espacio en el que se estaba pero ese espacio es precisamente lo que se abandona al inicio del viaje: el habitante viaja con sus hábitos pero sin su hábitat. La casuística que encierra esta tensión y los modos en que puede ser encarada son ciertamente numerosos (como en el caso extremo de querer desprenderse de todo hábito que recuerde una vida pasada) pero lo importante, en este momento, es apuntar a la existencia de esta tensión que está en el núcleo mismo de la movilidad y que si a veces no se vive como tensión -lógicamente los turistas que esperan a coger un vuelo que les lleve a un destino lejano no están tensionados sino que se les supone ilusionados en el inicio de su período estival- es porque ese desplazamiento opera sobre la base de un proceso sociohistórico que permite diluir dicha tensión al haber modificado los espacios a los que se va para que allí se pueda seguir, de un modo u otro, con los hábitos que se tenían. La movilidad encierra así un momento de posible reconfiguración, más o menos consentida, más o menos violenta, de la trama de hábitos que subyace a la ontología biopolítica de la habitabilidad. Volveremos sobre este punto, crucial en nuestra argumentación, al hablar de la domesticación de los espacios.

Íntimamente ligada a la anterior, la segunda dimensión de la movilidad en la que queremos incidir es la que alude al modo en que se resuelve el encuentro, en la zona de contacto que propicia el viaje, entre el que está y el que llega. Esta cuestión nos introduce en toda una temática que orbita en torno al modo en que se gestiona la hospitalidad y a la posibilidad de que ésta se transmute en hostilidad. Las viejas figuras hospes y hostis (Benveniste, 1983), actúan como extremos de las diversas formas en las que se resuelve el hecho, portador él mismo también de una tensión más o menos explícita, de que quien llega, ya sea porque está de paso, ya sea porque quiere quedarse, precisa de un lugar en el que poder estar por un tiempo variable; la hospitalidad, entendida en un sentido incondicionado, no sería sino la capacidad para ofrecer al que viene un lugar en mi lugar sin preguntar quién es y por qué 
viene: la hospitalidad da lugar, habilita un espacio a quien llega (Derrida, 2006). Pero esto no sería sino una abstracta ley de la hospitalidad que al adquirir diferentes concreciones comienzan a horadar esa incondicionalidad que se le presupone a una hospitalidad entendida en su sentido más radical: habilitar un lugar sin preguntar para quién será ese lugar: "No existe hospitalidad, en el sentido clásico, sin soberanía del sí mismo sobre el propio-hogar, pero como tampoco hay hospitalidad sin finitud, la soberanía sólo puede ejercerse filtrando, escogiendo, por lo tanto excluyendo y ejerciendo violencia. La injusticia, cierta injusticia, incluso cierto perjurio, comienza inmediatamente, desde el umbral del derecho a la hospitalidad" (Derrida, 2006: 59). En cualquier caso, se apunta aquí, de nuevo y como en la dimensión antes apuntada, a una tensión que da lugar a formas heterogéneas: el modo en que se resuelven las múltiples concreciones de la hospitalidad nos lleva a una temática de muy largo recorrido que incorpora toda una serie de narrativas desde las cuales se nomina simbólicamente a quien pretende habitar mi hábitat y que se extiende, en lo que a la hostilidad se refiere, desde la clásica figura del bárbaro hasta la actual criminalización de los inmigrantes y, en lo relativo a la hospitalidad, desde el relato de la Odisea-que es en sí mismo un tratado de hospitalidad referido a cómo tratar al extranjero- hasta el diseño de una hospitalidad planificada para acoger al turista con todas las comodidades que precise.

Las dos dimensiones apuntadas de la movilidad, la reconfiguración de los hábitos y la acogida hospitalaria-hostil al viajero, acontecen así como dos caras de un mismo proceso que rige el modo en que se concibe, practica y vivencia el hecho de quedar sumido en el desplazamiento. La primera remite al modo en que se mantienen los hábitos, la segunda al modo en que se accede a un hábitat; diferenciación esta más analítica que empírica ya que la movilidad las entrevera y las torna, en la práctica, indisociables. Ambas componen el rostro bifronte en torno al cual se estructura la ontología biopolítica de la habitabilidad cuando la ponemos en conexión con la movilidad, ambas confieren, en su entrelazamiento, la distintividad que aflora en la conformación de cada régimen de movilidad. La anteriormente mentada deconstrucción de la subjetividad sobre la base de una geografía crítica que torna al sujeto en habitante de los hábitos-hábitats que le preceden, no podría llevarnos a retomar la idea del viajero decimonónico en donde se ensalza su individualidad (masculina) y se condensan los imaginarios de la modernidad articulando así un topos narrativo que desdibuja la realidad material del viaje para recrear un mito (Clifford, 1995). Antes que el viajero están las formas del viaje, los regímenes de movilidad que sobre la base de sus tiempos, espacios, relaciones de poder y subjetividades, habilitan el desplazamiento y el modo en que éste acontece.

Sería conveniente, por ello, no tanto referirnos en un primer momento al sujeto concreto que se mueve cuanto perfilar los contornos de los distintos regímenes de movilidad existentes (con sus peculiaridades político-económico-jurídicas) para ubicar ahí, ahora sí, con toda su particularidad, al sujeto móvil en su especificidad; o dicho de otra manera, la biopolítica de la movilidad (formas de vida reconfiguradas) sobre su fondo de gubernamentalidad (ordenamiento de los espacios y los tránsitos). Y, junto a ello, tener siempre presente que los regímenes de movilidad también pueden producir regímenes de inmovilidad al establecer todo un entramado de fronteras de diverso signo (físicas, jurídicas, policiales) que impiden o dificultan la movilidad misma fijando las personas al espacio que habitan. Estaríamos, en cualquier caso, ante una distribución desigual de la capacidad para convertirse en sujeto-en-movimiento, lo que comporta, que duda cabe, no sólo distintas competencias de movilidad sino también distintos riesgos en función de las rutas que se transitan. La movilidad, en definitiva, no es ajena a las inmovilidades desencadenadas $\mathrm{y}$, a menudo, ambas funcionan como las dos caras de un mismo proceso.

En definitiva, la ontología biopolítica de la habitabilidad nos ubica en un escenario que, articulado en torno a las múltiples remisiones que se establecen entre hábitat-hábito-habitante, subraya la importancia de la espacialidad en tanto que requisito previo para acercarnos a pensar una movilidad que habrá de ser leída en función de la gubernamentalidad que la impregna y en el modo en que en su seno se resuelve tanto la reconfiguración de los hábitos como la acogida hospitalaria u hostil hacia los que llegan a otro espacio. Este es el sustrato teórico, sucintamente expuesto, desde el que encaramos la movilidad; y en esta necesidad de acogernos a una "translocalidad" (Clifford), a "un sentido global del lugar" (Massey), por medio del cual todo espacio 
lleva la huella de otros espacios como consecuencia de los distintos regímenes de movilidad articulados a lo largo de la historia, quizás podemos sugerir ya que el homo viator es otra de las posibles y necesarias caracterizaciones de lo humano, no tanto porque él mismo sea un viajero sino porque sus espacios, en un sentido radical, no se entienden al margen de los viajes que han conectado los espacios. La movilidad no puede ser, en este sentido, el signo distintivo de nuestros tiempos porque lo humano se ha pensado y practicado desde siempre en torno a la metáfora y la práctica del viaje; acaso tan sólo podríamos apostillar que hay formas de movilidad propias de cada tiempo, regímenes de movilidad desde los que trazar diferencias. Desde ese sustrato podemos acercarnos ya a una reflexión acerca de la relación entre modernidad, movilidad y espacio leída en clave de domesticación multiforme que deja su huella en los regímenes de movilidad.

\section{LA MODERNIDAD Y LA DOMESTICACIÓN DEL ESPACIOD}

La historia del viaje es la historia de una relación, por una parte, con lo predestinado y, por otra, con lo incierto. El viaje clásico, si tomamos como ejemplos paradigmáticos la Odisea o La epopeya de Galgamesh, es un viaje marcado por toda una serie de designios divinos que no suponen tanto la difuminación del protagonista en el marco narrativo regido por lo divino (difícilmente podríamos suscribir algo parecido de un personaje como Ulises que encarna de forma paradigmática la metis y el kairos) pero sí es cierto que el decurso mismo del viaje queda mediado por el hacer y decir de los dioses. Igualmente, lo incierto queda como el espacio que se abre cuando se traspasan los límites de la ecumene, cuando las columnas de Hércules quedan atrás y los hábitos que pautaban la cotidianidad del hábitat reconocible apenas designan una referencia estable y fiable ante lo que se puede encontrar: la ingente producción de monstruos y mirabilia no es sino la consecuencia lógica de un adentrarse en un espacio desconocido: "En su recorrido espacial, difícilmente el navegante encontrará lo maravilloso dentro de los límites de lo conocido. La maravilla por su condición, se manifiesta a partir de las zonas fronterizas y siempre en dirección a los extremos, puesto que la periferia y el confín invariablemente han sido espacios fecundos para la germinación de maravillas" (Soler, 2003: 209). La geografía del viaje que limita con lo desconocido se torna en una geografía simbólica que, en su propia especificidad, lleva la impronta de cada hábitat porque si bien éste queda atrás, los hábitos antes practicados son la única herramienta que se tiene para interpretar lo que se encuentra y lo que se imagina, articulando así un magma indiscernible entre lo real y lo simbólico: la terra incognita siempre ha estado mediada simbólicamente por los imaginarios de quienes la acechaban. A esto se refería Kappler en su seminal estudio sobre la Edad Media: "No se trata aquí de una distinción entre lo real y lo fabuloso, menos aún entre lo real y lo irreal: hasta el siglo XV no aparece una brecha semejante, todo es real. Más que a una discriminación vertical entre niveles de realidad, se asiste a una confrontación horizontal (espacial, cabría decir) entre el aquí y el allá, lo familiar y lo extraño, lo ordinario y lo unheimlich" (1986: 91).

La historia del viaje en la modernidad, los regímenes de movilidad que comienzan a articularse, responden, en gran parte, a esa "confrontación espacial" que liga el aquí y el allá de un modo tal que elimina progresivamente toda huella de una predestinación de signo divino al tiempo que se intenta sacar al espacio desconocido de la opacidad en la que antes permanecía. El estatuto del viajero ya no es tanto el de un mediador que conecta y narra el vínculo entre conocido y lo desconocido cuanto un desvelador de lo oculto y, así, la propia narrativa del viaje irá cambiando para asumir los valores de objetividad y exactitud que se autoconfiere la modernidad (Pimentel, 2003). Eliminar lo predestinado y el asombro; sobre esta doble faz se despliegan las movilidades modernas: el agres griego; el eremos judeocristiano, la floresta medieval, toda esa red de espacios difícilmente habitables que adquieren sus manifestaciones más evidentes en el desierto, el mar o el bosque irán siendo paulatinamente despojados de la incertidumbre que traía el transitar por ellos: "El hombre del viaje, en su búsqueda, iniciará una vez más el proceso de humanización de la nueva distancia, el tiempo, el espacio, para poder volver a dominar el sentimiento de inseguridad" (Soler, 2003: 205).

En este proceso, aquí tan sólo reseñado en sus manifestaciones más sobresalientes, podríamos con- 
cluir que la modernidad se abalanza sobre el espacio para poseerlo e introducirlo en una cartografía geométrica y sobre el tiempo para administrarlo y encerrarlo en un dispositivo cronométrico. El abandono de una cartografía medieval más concernida con lo cualitativo, con la experiencia simbólica de los lugares, con los recorridos (que, en su mayor parte, quedaban circunscritos a los peregrinajes), y su sustitución por una geometría concernida con la correcta ubicación de los lugares en el mapa muestra el profundo cambio en la relación con el espacio. La historia de la cartografía ejemplifica un nuevo ethos concernido con ese eje rector de la modernidad que es la apropiación y el dominio del espacio (Harvey, 1997). El reloj, en este sentido, no será sino la proyección en lo temporal de lo que el mapa renacentista realiza con el espacio: las distintas formas de medir y experimentar lo temporal irán siendo progresivamente suplantadas por el dispositivo del reloj que geometriza el tiempo y lo matematiza sustrayéndolo de su dimensión cualitativa y vivencial. No es extraño, en ese sentido, que, más adelante, cuando se comience ya a emplear el reloj de un modo más extendido, éste quede concebido como el dispositivo más relevante de la revolución industrial (Munford, 1994) a través del cual se reglamenta y disciplina la producción laboral o que la coordinación horaria se convierta en un requisito ineludible en la organización de los flujos comerciales.

Sobre la base de las reflexiones previas se puede ya enunciar las dos ideas que queremos enfatizar en este epígrafe al analizar la relación entre modernidad y movilidad. La primera de ellas es que el descubrimiento queda convertido en "la palabra rectora de la época", el "superacontecimiento de la toma y registro de la tierra" en torno al cual se articulan un "conjunto de prácticas mediante las cuales lo desconocido se transforma en conocido, lo no-representado en representado o registrado" (Sloterdijk, 2004: 781). La noción de descubrimiento no sólo quedará ubicada en el núcleo central de una epistemología positivista (Woolgar, 1991), sino que también condensa un imaginario que no está únicamente concernido con saber qué es lo que hay más allá de lo conocido sino que el acto de conocer, la práctica del des-cubrir, activa o, mejor, va ella misma acompañada de toda una serie de procedimientos mediante los cuales los espacios descubiertos son apropiados, mostrando así que el paso determinante no es el de lo desconocido a lo conocido cuanto a lo poseído. El indudable componente de aventura que acompañó el asalto a lo desconocido quedará paulatinamente envuelto en una lógica de disciplina, control y seguridad en torno a la cual habrán de gestionarse los espacios descubiertos: "La aventura se convierte en guerras, planes de dominio e ideales evangelizadores" (Soler, 2003: 81-2). La modernidad, como acertadamente ha sugerido Sloterdijk, acaba negando aquello que la posibilitó: "Pertenece a las ironías de la modernidad el que tuviera que prohibir, retroactivamente, todo lo que emprendió y arriesgó para hacerla realidad" (2004: 778).

La segunda idea, que tomamos igualmente del filósofo Sloterdijk, y que en cierto modo no es sino la consecuencia de la estrecha conexión desatada entre el descubrimiento y la posesión y dominio de lo descubierto, es la quiebra de lo local cuando se instaura una movilidad globalizante pasada por el tamiz de la mercancía: "La historia de la edad moderna no es, en principio, otra cosa que la historia de una revolución espacial en el exterior. Consuma la catástrofe de las ontologías locales. En su transcurso, todas las naciones antiguo-europeas se convierten en emplazamientos sobre una superficie esférica, y todas las ciudades, pueblos, paisajes se transforman en puntos de tránsito en la circulación ilimitada de los capitales bajo su quíntuple metamorfosis de mercancía, dinero, texto, imagen, prominencia" (Sloterdijk, 2004: 717; el subrayado es añadido). La movilidad globalizante compone una compleja y cambiante topología del espacio que, en virtud del tipo de relaciones de traza, socava en muchos lugares la cotidianidad sobre la que se estructura el espacio, los hábitos que recreaban el hábitat, recordándonos que la zona de contacto que ahí se abre no depara tanto un contacto entre iguales cuanto entre sujetos ubicados diferencialmente en una jerarquía de lo humano y es en virtud de esa diferencialidad que a esa zona de contacto se le exige disponibilidad para que quede constituida en un nodo de conectividad por el que transitarán personas, cosas e ideas: disponibilidad del hábitat (para producir lo necesario, para extraer sus riquezas, para comercializar las mercancías), disponibilidad de los habitantes (para reconvertirlos en mano de obra, para llevarles como esclavos a otros hábitats). La exigencia de disponibilidad -de clara raigambre colonial, tal y como más adelante volverá a enfatizarse- es el eje en torno al 
cual se consuma con más virulencia la catástrofe de las ontologías locales, la des-re-estructuración de los hábitats.

Esta doble idea que transita entre la práctica del descubrimiento (para tomar acta de posesión y dominio) y el desencadenamiento de la catástrofe de las ontologías locales (mediada por la exigencia de disponibilidad) viene a subrayar, en oposición a esa idea autocentrada de la modernidad en tanto que despliegue de unos modos de hacer y pensar propios, la importancia del viaje en la conformación de la modernidad. Importancia espacial y simbólica; espacial porque es en torno al viaje, a los regímenes de movilidad desplegados, que se compone (con sus desigualdades internas) la geografía específica de la modernidad; y simbólica (Kaplan, 1996; Van den Abbeele, 1992) porque en el viaje tiene lugar toda una producción de conocimiento que remite al modo de relacionarse con otras culturas, razón por la cual el viaje no puede ser ya algo que quede sujeto a las apetencias del aventurero sino que, por el contrario, se debe seguir todo un procedimiento estructurado desde el que se establece el modo en que ha de realizarse la práctica misma del viaje.

Brevemente, y en lo referido a la dimensión simbólica, cabe apuntar que el reflejo más evidente de ello es el llamado arte apodémica renacentista (Sta$\mathrm{gl}, 2005)$ en torno al cual se elabora todo un corpus normativo que rige el proceder del viaje, de marcado carácter educacional, para que ya no sea una mera exposición de las impresiones subjetivas del viajero cuanto un tratado que establece el modo en que ha de recogerse la información (metodología de la observación) y el modo en que ha de ser contada (retórica objetivizada). El breve escrito de Bacon sobre los viajes vendrá a condensar toda esta forma de entender y practicar el viaje tanto por el procedimiento que establece (conocimiento del idioma del lugar que se visita, llevar diario, no estar mucho tiempo en el mismo sitio, cambiar de alojamiento en una misma ciudad, separarse de sus compatriotas, conocer a la gente relevante del lugar visitado, discreción...) como por el hecho de que el viajero no debe quedar afectado por lo que visita: "Cuando el viajero regrese a su patria, que no olvide completamente los países por los que viajó sino que mantenga correspondencia epistolar con aquellas de las personas conocidas que más lo merezcan; que sus viajes aparezcan más en su conversación que en su atuendo y maneras; que en su conversación sea cauto en las respuestas y no propenso a contar anécdotas; y que se vea que no cambia sus costumbres patrias por las extranjeras sino que sólo ponga flores de las que ha conocido fuera entre las costumbres de su patria" (Bacon, [1625] 1980: 84; el subrayado es añadido). No podría expresarse de un modo más nítido: la experiencia del viaje mantiene incólume la subjetividad del viajero que tan sólo podrá permitirse veleidades ornamentales.

Lo determinante, en todo caso, para la argumentación que aquí se sugiere, es que esa centralidad geográfica y simbólica del viaje ha estado atravesada por la necesidad de domesticar la movilidad y los espacios afectados por esa movilidad. La idea de domesticación de los espacios y los tránsitos no ha de entenderse en el sentido de un intento por homogeneizar el ámbito sobre el que se proyecta con el fin de conseguir un orden que funcione a modo de maquinaria perfectamente regulada que reproduce unas normas previamente fijadas. La domesticación es, por el contrario, un dispositivo de captura que altera los ordenamientos a través de los cuales se rigen esos espacios, una regulación de los mecanismos de reproducción de la existencia no tanto bajo la forma de un panóptico centralizado que rige el devenir del espacio sino a modo de un entramado político-económico-jurídico que incide en modo en que han de reconfigurarse las relaciones entre el hábitat-hábito-habitante con lo que se ubica en el andamiaje mismo de las formas de vida, en sus engranajes constitutivos para amoldar las conductas y conducciones de los sujetos, para adaptarlas a un ordenamiento mutable que regula lo permisible. Domesticar en el sentido de proyectar lo propio de un lugar (el domus), de una forma de concebir el lugar, hacia otros espacios, recreando así una geografía de dominio por medio de una acción a distancia regida por normativas, tratados o acuerdos de diverso signo que rigen el modo en que ha de producirse la vida, la imbricación hábitat-hábito-habitante.

Domesticar los espacios pero también los tránsitos; dos caras de un mismo proceso que se asienta en el rechazo incondicional del movimiento que carece de un orden: el errante, el vagabundo, el nómada, el hobo, el que está en el camino porque no tiene un espacio propio desde el que moverse, el que ha hecho del movimiento un modo de vida, vendrá a ejemplificar el rostro multiforme de quien ha de ser 
vilipendiado y castigado por lo que es. Rousseau lo expresa de forma nítida: "Viajar por viajar es errar, es vagabundear; viajar para instruirse es todavía un objeto vago; la instrucción que no tiene una meta determinada no es nada" (1990: 619-20). Hay que saber viajar porque lo que aquí está en juego no es el moverse en sí mismo sino una(s) forma(s) de concebir la movilidad dotada(s) de sus propias normas que domestica(n) no sólo los espacios a los que se va sino a la propia movilidad para despojarla de lo imprevisible. La modernidad que encumbra la movilidad aborrece el movimiento no reglado y ello, tal y como ha mostrado de Gaudemar en su estudio clásico, tendrá un reflejo evidente en la conformación de la sociedad industrial: "No impedir la movilidad, sino controlarla. Y, desde luego, fijar incluso a veces la mano de obra: cuando esto constituye la forma óptima de control. Pero también dejarla vagar, con tal de que esta errancia tenga un final y colme, en alguna parte, un hueco de capital. Controlar siempre la movilidad, volverla útil, conferirle un poder económico fecundante" (1981: 39).

Deleuze y Guattari lo habían expresado con suma claridad: "Una de las tareas del Estado es la de estriar el espacio sobre el que reina, o utilizar espacios como medio de comunicación al servicio de un espacio estriado. Para cualquier Estado no sólo es vital vencer el nomadismo, sino también controlar las migraciones, y, más generalmente, reivindicar una zona de derechos sobre todo un "exterior", sobre el conjunto de flujos que atraviesan el ecumene. En efecto, el estado es inseparable, allí donde puede, de un proceso de captura de flujos de todo tipo, de poblaciones, de mercancías o de comercio, de dinero o de capitales, etc. Pero se necesitan trayectos fijos, de direcciones bien determinadas, que limiten la velocidad, que regulen las circulaciones, que relativicen el movimiento, que midan detalladamente los movimientos relativos de los sujetos y los objetos. De ahí la importancia de la tesis de Paul Virilio, cuando muestra que "el poder político de Estado es polis, policía, es decir, red de comunicación" " (Deleuze y Guattari, 1998: 389). La gubernamentalidad irrumpe aquí como la policía del espacio, como el teatro de fondo de la biopolítica, como la arquitectura más o menos oculta de la movilidad que transita entre espacios: "El Estado no cesa de descomponer, recomponer y transformar el movimiento o regular la velocidad. El Estado como inspector de caminos, transformador o échangeur routier: papel de ingeniero a este respecto" (Deleuze y Guattari, 1998: 390). De esto se trata, en definitiva, de domesticar la circulación, las rutas, las velocidades, los sujetos y los objetos que las recorren; una regulación del entrelazamiento de los hábitats que tiene consecuencias para sus habitantes, para sus hábitos: capturar los espacios para reestructurar sus ordenamientos, para regular sus conexiones, pero también abandonarlos cuando carecen ya de interés (la empresa multinacional que cambia de lugar de producción buscando espacios más rentables).

Este escenario de creciente domesticación de la movilidad, leído en clave foucaultiana, y proyectándolo hacia el desarrollo mismo de la modernidad, supone reconocer que ya no estamos en un escenario marcado por el omnipotente decir y hacer del soberano que disponía de la vida de los súbditos de un territorio determinado y cuyo poder refulgía en su capacidad para dar muerte, en un hacer morir y dejar vivir (Foucault, 1995, 2003) que articulaba su propia ley para imponer el modo en que había que vivir una vida que colindaba inquietantemente con la posibilidad de la muerte dictada por el soberano; y reconocer, asimismo, que tampoco estamos en un escenario marcado por el encierro disciplinario que proyecta el poder sobre los sujetos mediante una "anatomía política del detalle" que rearticula los cuerpos, su trama de hábitos, para aumentar su utilidad económica y disminuir su potencia problematizadora con miras a la consecución de cuerpos dóciles, disponibles y moldeables. No, ya no nos define ni la potencia del soberano sobre los súbditos de su territorio (su poder discrecional para prohibir-permitir), ni el poder disciplinario del encierro (su poder para aplicar la norma y sancionar su incumplimiento) y, sin embargo, éstos no acaban de desaparecer, se mantienen pero operan ya en un contexto marcado por una gubernamentalidad concernida, en el enfoque de Foucault, mayormente con dispositivos de seguridad que en su heterogeneidad incorporan, modulándolos, rasgos de épocas pretéritas. Y aquí de lo que se trata es del poder para regular la conformación cambiante de los espacios y los tránsitos que los atraviesan: "Ya no fijar y marcar el territorio, sino dejar fluir las comunicaciones, controlarlas, seleccionar las buenas y las malas, permitir que la cosa se mueva siempre, se desplace sin cesar, vaya perpetuamente de un punto a otro, pero de tal 
manera tal que los peligros inherentes a esa circulación queden anulados. Ya no la seguridad del príncipe y su territorio, sino la seguridad de la población $\mathrm{y}$, por consiguiente, de quienes la gobiernan" (Foucault, 2006: 86). La domesticación es la captura y regulación de los espacios y los flujos en un entorno mutable que va definiendo contingentemente lo permisible y aceptable y es, por ello, que no homogeneiza sino que administra la heterogeneidad en su puesta en relación.

Gestión descentralizada de la movilidad, de lo que se puede mover y de cómo se debe mover sobre la base de normativas que establecen las reglas del juego, la producción jerárquica, desigualmente repartida, de la movilidad. No pretendo subsumir la heterogeneidad de las formas de viaje en un único régimen de movilidad pero sí al menos sugerir que la movilidad moderna ha estado mayormente marcada por un ethos que busca la domesticación de los espacios y de la movilidad misma. El conocido dictamen de Baudelaire: "Pero son los viajeros de verdad los que parten por partir" nos recuerda esa heterogeneidad de las prácticas de viaje, los modos harto disímiles en los que se acomete el viaje pero también ilumina, a contraluz, que el viaje profundamente asociado con la modernidad -con esa modernidad ajardinada que diría Bauman- no es nunca un partir por partir, es un partir con un sentido determinado: viaje de conocimiento reglado, viaje de apropiación.

Si en el epígrafe anterior concluíamos que la estructura de la movilidad se asentaba en un doble pilar que alude tanto al modo en que se reconfigura la relación hábito-hábitat-habitante como a las formas en que se practica la hospitalidad-hostilidad en la zona de contacto, la movilidad moderna bien podría quedar caracterizada, en sus rasgos más sobresalientes, por una domesticación del espacio (que al exigir y demandar la disponibilidad de esos espacios da lugar a profundas reestructuraciones de la triada hábito-hábitat-habitante) llevada a cabo de un modo hostil (fundamentada en una jerarquía de lo humano que deshumaniza al otro). Apropiarse del espacio y reglamentar la movilidad para gubernamentalizar las conductas y los conductos y aquí, en este proceso multidimensional que adquiere manifestaciones muy diversas, todo un entramado de violencias simbólicas y materiales acompañan esa domesticación hostil que incorpora la arbitrariedad-impunidad del soberano y la lógica punitiva de lo disciplinar en el campo de actuación securitario. Este es el trasfondo que también hoy, en la modernidad tardía, vemos reproducirse y es, por ello, que una vez visto en el segundo epígrafe el modo en que conceptualizábamos el régimen de movilidad y, en el tercero, el ethos dominante que permea los regímenes de movilidad modernos, podemos acercarnos ya a escenarios más cercanos a nuestro presente para entrever las formas en las que sigue aconteciendo esa domesticación hostil.

\section{REGÍMENES DE MOVILIDAD EN LA MODERNIDAD TARDÍA}

Es necesario realizar una matización sobre el propio concepto de viaje antes de reflexionar sobre la movilidad en la modernidad tardía. El concepto de viaje está muy lejos de ser un concepto que tan sólo mienta un mero desplazamiento por el espacio; el viaje, como la idea de movilidad, está impregnado de un imaginario que traza los lindes de su aplicabilidad y le confiere unos determinados sentidos que le llenan de contenido y reconocimiento. Al viaje se le presupone un cierto alejamiento de lo reconocible, una inmersión en un espacio que no está enteramente programada de antemano, de modo que el asombro deviene parte constitutiva de todo viaje, un asombro que emerge cuando se contempla lo inesperado, cuando el azar nos golpea con sus caprichos, cuando sobreviene una experiencia que resquebraja la habitualidad que antes habitábamos: no hay viaje -algo que merezca ser llamado viaje- sin asombro. Será, por ello, el aventurero, aquel que busca lo incierto, quien se adentra en lo desconocido para asombrarse de lo que (todavía) se puede ver, el que se avenga a encarnar de un modo paradigmático la idea de viaje. Decir que no hay viaje sin asombro es decir que no hay viaje sin ruptura con la habitualidad que habitamos, que el viaje nos aleja no sólo de donde estábamos sino también, en un sentido más profundo, de lo que éramos y, por eso, en el empleo metafórico que se hace del viaje se podrá aludir a viaje inmóviles (a la manera de Xabier de Maistre o Fernando Pessoa) que no son sino un descenso a lo más hondo de la cotidianidad que habitamos para ver ahí los materiales con los que estamos hechos, acaso para vernos de otro modo. Adentrarse en el 
asombro, romper con lo cotidiano, partirnos tras la partida; esto es lo que hace el verdadero viajero pero esto, habría que añadir inmediatamente, tan sólo es el imaginario del viaje, su mito constituyente (Clifford, 1995) que lo ubica en el sujeto ensalzado por la modernidad: varón blanco occidental. Las mujeres apenas fueron partícipes de este imaginario que encumbró al aventurero decimonónico y qué decir de los indígenas que acompañaban a los aventureros; la idea de viaje viene así simbólicamente marcada tanto en su contenido como en el sujeto que la encarna. Y si acaso el paso del tiempo ha podido horadar esa subjetividad para ensancharla más allá de los márgenes en los que estaba confinada, el propio sentido que designa el viaje, su asombro constitutivo, permanece como su seña de distinción y será, por ello, en estas sociedades espectacularizadas que han ensalzado el turismo masivo, donde ya se conoce de antemano lo que será el espacio y el tiempo del viaje, donde lo visitado ya ha sido visto anteriormente en multitud de imágenes, donde la aventura se prefabrica y el asombro se confecciona para satisfacer al turista, donde el retraso quizá sea el último rescoldo de la aventura (Sloterdijk), que se nos dirá, a modo de topos repetido rutinariamente, que el viaje ha desaparecido, que el viaje nos es ajeno, que el turismo ha matado el viaje (Auge).

No es momento de analizar en profundidad esta escisión que pone frente a frente al viajero y al turista pero sí al menos de sugerir que dicha escisión, que ha devenido lugar común, a menudo se realiza sin deconstruir el imaginario que impregna la noción de viaje, con lo que el propio viaje corre el riesgo de quedar convertido en imagen mitificada desde la que establecer la crítica de ese turista convertido ya en el despreciable sujeto de masas por excelencia, aquel, por utilizar un expresión de Nietzsche, que no viaja sino que se le viaja, aquel que viaja por viajar, por cambiar de sitio, el sujeto que transita pasivamente por rutas marcadas para consumir lugares despreciando su hondura sociohistórica; los reproches que atesora el turista se extienden desde su confrontación con las élites que protagonizaban el grand tour hasta las actuales críticas que, no sin caer en cierto elitismo, evidencian en el auge del turismo la muerte del viaje (Urbain, 1993). Pero si el viaje mitificado nos aleja de las especificidades propias de cada viaje, la crítica sin matices del turismo nos aleja de la vivencia de este tipo de viaje. Y lo que aquí nos inte- resa son las prácticas de viaje, la práctica de la movilidad tal y como tiene lugar en el espacio, el modo en que los espacios se ven transformados por ella, razón esta que nos lleva, igualmente, a no suscribir el uso expansivo de la figura del nómada en tanto que sujeto glorificado de las sociedades posmodernas dado que ahí se vuelve a ensalzar simbólicamente el movimiento sin atender a las concreciones sociomateriales del movimiento, a las subjetividades que lo protagonizan (y que a menudo lo padecen) (Creswell, 2006).

Quizás, todo ello, no sea sino consecuencia del potencial simbólico que el propio acto del viaje evoca (presente desde las primeras narraciones que lo humano se cuenta a sí mismo) y que, de un modo u otro, también se refleja en la escisión que se abre entre el viaje (impregnado de connotaciones positivas y de intencionalidad) y el desplazamiento (impregnado de todo un halo de necesidad que socava su positividad). Si bien la contraposición entre viajeroturista operaba en un plano marcado por la autenticidad del asombro, la escisión viaje-desplazamiento funciona en el plano definido por el margen de intencionalidad. El análisis de Bauman (2001) es deudor de esta lectura al sugerir que los turistas y los vagabundos-migrantes constituyen no sólo las manifestaciones más clarividentes de la movilidad sino también las grandes metáforas de nuestras sociedades, una suerte de condensación simbólica en donde ver nítidamente la doble faz de la movilidad imperante que se abre a la libertad y a la necesidad: "Los turistas viajan porque quieren; los vagabundos porque no tienen otra opción" (ibídem: 118); al deseo y a la hostilidad: "Los turistas van de un sitio a otro porque el mundo les parece irresistiblemente atractivo, los vagabundos van de un sitio a otro porque el mundo les parece insoportablemente inhóspito" (ibídem: 118). Obviamente, podríamos aludir a un amplio repertorio de movilidades que no son partícipes de la contraposición turista-vagabundo pero sí es cierto que esta doble faz alude a todo un elenco de viajes-desplazamientos que poseen una indudable centralidad en la conformación de nuestras sociedades, como si el turista-vagabundo estuviese de tal modo incrustado en nuestros espacios que, si nos desprendiésemos de ese par, el mundo que habitamos se tornaría irreconocible. La intuición de Bauman tiene sin duda su interés pero carece de anclaje teórico con la propuesta teórica que aquí se suscribe 
toda vez que su planteamiento contiene un cierto sesgo teleológico en torno a esa incertidumbre cada vez más omnipresente que quiebra todo proyecto duradero dejándonos un mundo que, metafóricamente, se lee a modo de "un juego en el que las reglas se hacen y rehacen mientras se juega" (ibídem: 112), lo que, en última instancia, vendrá a desencadenar que la identidad, al no poder fijarse, se adopta y se desecha "como quien cambia de vestido" (ibídem: 113). Aproximación esta diametralmente opuesta tanto a la ontología biopolítica de la habitabilidad como a un análisis en clave de gubernamentalidad que profundiza en el entramado de racionalidades y tecnologías por medio de las cuales se producen los espacios que habitamos y las (in)certidumbres que en ellos sentimos.

Y es así, en consecuencia, que el análisis de las movilidades desplegadas en torno a la contraposición turista-vagabundo exige, a nuestro juicio, desligarla de la dicotomía viaje-desplazamiento (es por ello que en las páginas precedentes se ha utilizado de forma indistinta viaje y desplazamiento), liberarla de los sentidos que se desprenden de un imaginario moderno del viaje que marca cuál es el verdadero viaje y quién es el verdadero depositario del asombro, para aludir a la producción concreta de la(s) movilidad(es) de los turistas-vagabundos atendiendo a sus espacios y tiempos, a sus relaciones de poder, a las subjetividades que se (re)producen. Hay que gubernamentalizar la movilidad para desbrozar las formas en las que se articula y se vivencia. Ello, digámoslo una vez más para evitar equívocos, no conlleva diluir al sujeto concreto que se desplazaviaja sino tan sólo reubicarlo como habitante de un régimen de movilidades que le precede, un régimen que es mutable y que no es ajeno, asimismo, a las dinámicas de otros regímenes de movilidad con los que puede coexistir: no cabe hablar en rigor de una movilidad -a la manera de una racionalidad que lo englobase todo- en tanto que definitoria de nuestro tiempo: hay movilidades (del mismo modo en que no hay gubernamentalidad sino gubernamentalidades).

Desde estos presupuestos previos, sucintamente expuestos, cabe ya explicitar el argumento central de este epígrafe: los regímenes de movilidad configurados en torno al turista-vagabundo pese a las evidentes disparidades que contienen (tanto entre ellos como las que de hecho hay dentro de cada ámbito) actúan en el marco de unas racionalidades y tecnologías que tienden a reproducir la anteriormen- te aludida lógica de domesticación de los espacios, sin que ello suponga afirmar que ésta sea la única lógica existente y que, asimismo, se manifieste de forma unívoca: la domesticación es un fondo que acontece adquiriendo formas diversas, un hacer y decir que busca ensanchar su dominio en la gestión de la movilidad haciendo frente a las prácticas que la problematizan, a las líneas de fuga que escapan de la codificación. Y es en esta gestión descentrada, multidimensional, de los flujos migratorios y turísticos inmersa en los límites de lo permisible-deseable, que podemos acercarnos a un triple eje que actúa, en su entrelazamiento, como arquitectura de la gestión de las movilidades, un triple eje que se manifiesta de modos cambiantes dando lugar a distintas formas de habitar. Ejes que remiten a un hacer sobre el modo en que se ordenan los espacios, un actuar sobre las posibilidades de acción de los sujetos, el andamiaje de la biopolítica.

En una sucinta mención de ese triple eje, cuyo desarrollo exigiría sin duda un mayor espacio del que aquí disponemos, habría que hacer alusión a lo neoliberal entendido como un violento proceso de financiarización, mercantilización y privatización de los espacios operado mediante una "apropiación por desposesión" (Harvey, 2003) que refuerza la ya aludida crisis de las ontologías locales sumiéndolas en una lógica de la disponibilidad que se rearticula en paralelo a las indisponibilidades que problematizan este proceso. Lo neoliberal desencadena una quiebra de lo común para cimentar la apertura de los espacios a una mercantilización tejida en torno a lo político-económico-jurídico; y ello ocasiona un desarrollo geográfico desigual que, allí donde se instalan en mayor medida las desigualdades-exclusiones, propicia que el hábitat que se habitaba, pasado por el tamiz de la mercantilización-disponibilidad, a menudo ya no es el espacio en el que se pueda o se quiera vivir. Irrumpirá así la necesidad de migrar (como consecuencia, por ejemplo, del agotamiento de caladeros en el África subsahariana dejando a las poblaciones pesqueras locales sin su medio de vida básico o de la reconversión de tierras para la agricultura intensiva en países de Sudamérica que quiebran usos y entornos locales) o la imposición de tener que irse (lo que a menudo ocurre, por ejemplo en Colombia, cuando se habitan tierras ricas en recursos naturales que se van a explotar o cuando el espacio habitado se compra -tal y como está sucediendo en varios países de África- por inversores extranjeros como forma de especulación o para introducir una agricultura intensiva que exporta lo que produce o que especula en los mercados financieros con la adquisición de tierras). El turismo, por su parte, en 
modo alguno es ajeno a una lógica neoliberal que busca apropiarse de los lugares para que las grandes empresas del sector gestionen la conducción de los turistas en un proceso que deja a menudo una profunda huella ecológica y social en hábitats locales (podríamos pensar en zonas de turismo masivo del Caribe o de la propia costa del Mediterráneo pero también en ciudades muy turistizadas como Barcelona o Venecia que ven alterado de un modo notorio las formas locales de ocupar y vivenciar los espacios); la neoliberalización de los espacios se abre así, tanto a una lógica de la expulsión (desencadenante de la migración) como de la atracción (desencadenante del turismo) y, sin embargo, pese a su evidente disparidad, ambas lógicas comparten bajo prismas diferentes una gubernamentalización que domestica los espacios y los tránsitos.

En estrecha conjunción con lo neoliberal, encontramos el eje neocolonial que reproduce un dispositivo epistemológico-político-económico asentado en una jerarquía de lo humano (convirtiendo a los otros en desechos prescindibles) y una exteriorización de la naturaleza (perpetuando una lógica cimentada en el desarrollo y el crecimiento -que apenas se disimula en el oximorón desarrollo sostenible- que ha dado lugar a toda una serie de desastres socioecológicos). La colonialidad del poder (Quijano, 2005) sienta así las bases tanto de la inferioridad del otro como de la capacidad para aprehender el espacio del otro, ubicándose en la arquitectura misma del despliegue de la modernidad, de esa modernidad que, en virtud del entramado simbólico de corte emancipativo con el que se rodea e impregna, acaba por negar aquello que la posibilita en su despliegue efectivo, ubicando, en consecuencia, a la colonialidad en el lado oculto de la modernidad (Mignolo, 2003), en aquello que ha quedado adherido indefectiblemente a la modernidad y que muta con ella acompañándola hasta el presente, hasta los regímenes de movilidad que hoy se (re)producen y cuyas visualizaciones son evidentes tanto en la criminalización de los sujetos migrantes como en ese boyante turismo étnico que encierra nuevas formas de racismo (MacCannell, 2007).

La estrecha relación entre lo neoliberal y lo neocolonial acontece como un dispositivo multidimensional desde el que se reestructuran los espacios de un modo tal que se acomete una producción continuada de habitantes sin hábitat, hábitats mercantilizados que socavan las formas de vida existentes, hábitats en los que ya no cabe reconocerse ni encontrar un proyecto de vida, lo que desencadenará la migración, el abandono-expulsión de esos lugares. La producción de habitantes sin hábitat se convierte así en uno de los grandes signos de esta época: habitantes que migran en la búsqueda de otros espacios en los que poder vivir y que pasan a habitar campos de refugiados (Agier, 2008), a engrosar los arrabales de megaciudades en condiciones muy precarias de habitabilidad (Davis, 2007) o que se lanzan a unas rutas migratorias cada vez más precarias y vigiladas (VV.AA, 2008). Es así que este habitante sin hábitat será quien encarne, paradójicamente, el poso de incertidumbre asociado al imaginario del viajero moderno, el que sufre en mayor medida la tensión que subyace al viaje en la recomposición de los hábitos y en la búsqueda de un espacio, alejado de la hostilidad, en el que poder volver a habitar. No en vano, a los actuales migrantes subsaharianos se les llama, en su lugar de origen, aventureros.

A ello se le suma, como tercer eje, una vertiente securitaria que regula los flujos y los sujetos-objetos que los transitan. La seguridad, concepto fuertemente ligado a la razón de Estado, acaba por convertirse en el núcleo del discurso político actual, la finalidad última de toda política que apuntala su legitimidad en la protección frente a unas amenazas, más o menos difuminadas, que corren el riesgo de socavar nuestro vivir; de la antigua consideración del miedo como origen antropológico del vínculo político se pasa a una expansión ilimitada del miedo (carente ya de fronteras delimitadas, de tiempos prefijados) que exige una respuesta continuada para no caer en una incierta vulnerabilidad frente a lo que nos amenaza y es así que el miedo queda como referente inaprehensible, la sombra que nos acompaña y que enmascara en su continua invocación la propia contingencia del discurso securitario (Foessel, 2011). Desde ahí, bajo el influjo de un miedo que a fuerza de enunciarlo ha quedado naturalizado $y$, paralelamente, despolitizado, desgajado de su sociogénesis, la razón securitaria se presta a regular los flujos que activan lo neoliberal y lo neocolonial de un modo tal que más que cuestionar la movilidad, la expande pero quedando restringida a una serie de parámetros que pueden ser cambiantes: el miedo apuntala lo securitario administrando posicionamientos diversos y distribuyendo desigualmente la capacidad para moverse; movilidad sujeta a vigilancia, asegurar, de nuevo, que la movilidad no evoque el nomadismo, capturar lo móvil, arrancarlo del vacío de lo imprevisto. De ello se colige, en última instancia, que la producción gubernamental de movilidad actúa en conjunción con una biopolítica de la inmovilidad que, según las circunstancias, pretende fijar a unas determinadas personas a sus espacios (alzamiento de muros, control de fronteras, políticas de visados...) o, una vez que la movilidad ha traspasado lo 
permitido, fijarlas en espacios punitivos (centros de internamiento, cárceles).

Digámoslo una vez más: aquí ya no cabe referencia alguna a un panóptico que actuaría como centro de mando desde el que vigilar y gestionar los distintos tipos de movilidad. Asistimos, por el contrario, a un proceso multidimensional entrelazado, a un régimen de gubernamentalidad que regula los espacios y la conexión entre los espacios; el panóptico queda sustituido -tal y como propone Bigo (2008) retomando la noción de bando al analizar flujos migrantes-, por un ban-óptico en el que se solapan la dimensión discursiva (que recrea la sensación de inseguridad y el tipo de subjetividad que la encarna), la institucional (de carácter estatal e internacional), la espacial (control militarizado-tecnologizado del movimiento entre espacios que ha comportado, en el ámbito europeo, una exteriorización de las fronteras hasta las costas africanas y, en otro orden, el establecimiento de una geografía de centros de detención e internamiento para los sujetos en transito que se desplazan, desde la óptica legal, de un modo ilegal), la jurídica (normativa para la gestión de los movimientos y la expulsión de los migrantes) y las medidas administrativas (implementadas por las instituciones estatales y supraestatales para hacer frente a las infracciones de los que se desplazan sin acogerse a la normativa vigente). Multiplicidad de actores y procedimientos que, entrelazándose, operan en la orbita del discurso de la seguridad componiendo una movilidad gubernamentalizada en la que se observa una confusión cada vez mas creciente entre lo publico y lo privado, lo policial y lo militar, el interior y el exterior, lo que, por su parte, acontece como reflejo de una, asimismo, creciente indistinción entre seguridad e inseguridad, guerra y paz, orden y desorden, estado de excepción y estado de derecho.

Merece resaltarse este último elemento porque lo securitario, en el régimen gubernamental en el que se haya inmerso, se despliega de la mano de una lógica de la excepcionalidad que le permite suspender la norma cuando sea preciso con el fin de asegurar dicho régimen gubernamental. La excepcionalidad nombra una situación liminal por medio de la cual el poder se ubica al margen de la ley pero al mismo tiempo mantiene su pertenencia a la ley y, desde ahí, desde la amplificación del margen de maniobra (e impunidad) que permite ese estar fuera pero dentro de la ley, justificado por una necesidad inexorable, la excepcionalidad puede ser leída como un dispositivo de captura: "La excepción es el dispositivo original en virtud del cual el derecho se refiere a la vida y la incluye en él por medio de la propia suspensión, la teoría del estado de excepción se convierte entonces en una condición preliminar para definir la relación que liga al viviente con el derecho $\mathrm{y}$, al mismo tiempo, le abandona a él" (Agamben, 2004: 10). La excepcionalidad designa así un dispositivo de inclusión que opera mediante la exclusión, un captura que crea formas de vida mediante el socavamiento de una biopolítica afirmativa que habría de determinar cómo se quiere ordenar ese vivir: la excepcionalidad, convertida según Agamben, en "el paradigma de gobierno dominante en la política contemporánea" crea formas de vida sumidas en la intemperie, en la arbitrariedad de quien hace y dice la excepcionalidad, en la paulatina erradicación de la bios en una topología de campos que producen zoe, nuda vida. No vamos a entrar ahora en una crítica de la noción de campo y en el uso descontextualizado y excesivamente expansivo que Agamben hace de este término (véase el artículo de Agier en este monográfico), pero sí queremos mantener la ligazón entre excepcionalidad y el hacer securitario ya que éste, en las exigencias que demanda para hacer frente a las supuestas amenazas, ha acabado por incorporar la excepcionalidad en tanto que forma de hacer y pensar a cuyo través se despliega lo securitario.

La alusión a la excepcionalidad nos permite, siquiera sucintamente, retomar la idea de que las relaciones de poder que impregnan las formas de vida que se producen, el hacer-vivir que signa cada biopolítica concreta, incorpora de modos diversos el poder discrecional del soberano y el dispositivo disciplinar. No hay, como ya habíamos sugerido, una sucesión de dispositivos de poder cuanto un cierto entrelazamiento que da lugar a formas heterogéneas. No encontraremos ya el hacer-morir del soberano sustentado en una dramaturgia de violencia pública pero sí una huella de su discrecionalidad (Butler, 2006) en la amplificación de la lógica punitiva que el uso de la excepcionalidad confiere a lo securitario (patente en las normativas europeas que rigen la expulsión de los inmigrantes) e, igualmente, un régimen de producción de muerte que no opera tanto por la violencia directa llevada al cuerpo del súbdito cuanto por un hacer-dejar-morir (como consecuencia de esa desestructuración de los espacios y del modo en que se regula el tránsito entre espacios) que socava la vida misma, la posibilidad de seguir viviendo (Mendiola, 2009), con lo que cualquier análisis de las biopolíticas producidas debe serlo también de las tanatopolíticas que aquellas desencadenan (Mbembe, 2003) y de los modos en los que la excepcionalidad se proyecta sobre el cuerpo. Las miles de muertes de inmigrantes naufragados en el Mediterráneo o los suicidios de campesinos en el 
sudeste asiático que no pueden ya articular un plan de vida, son ejemplos incontestables de las formas que opera la tanatopolítica moderna, el hacer-dejarmorir que produce la gubernamentalidad actual. Del mismo modo, lo disciplinar, aunque operado sobre una base distinta a la "anatomía política del destalle" conducente a la obtención de cuerpos dóciles, también se reactualiza al reproducir su consigna central, maximizar la utilidad económica de los cuerpos disminuyendo su potencial político (Foucault): la necesidad por parte de los migrantes de introducirse en un mercado laboral que se caracteriza por unas menguantes condiciones laborales y que se despliega en conjunción con un repunte inquietante de lo punitivo (Wacquant, 2010), hace las veces de un dispositivo que ya no produce necesariamente cuerpos dóciles pero sí cuerpos que incorporan, en condiciones cambiantes, la exclusión y la desigualdad (Santos, 2005).

Podríamos concluir afirmando, en consecuencia, que lo neoliberal-neocolonial en tanto que doble eje que desestructura los espacios actúa así en conjunción con una descentrada razón securitaria que regula los movimientos desencadenados en ese hacer desestructurante (que, lógicamente, da lugar a posteriores reestructuraciones). La seguridad, su producción y gestión, está en el trasfondo de los hábitats que habitamos y ello se vierte tanto en los mecanismos de control-punitivos a través de los cuales se regulan los tránsitos migrantes como en los mecanismos simbólico-materiales (publicidad, guías, rutas, seguros, instalaciones vigiladas...) para erradicar lo imprevisible de los tránsitos turísticos. Pero, junto a ello, conviene no olvidar que el dispositivo securitario, tal y como es formulado por Foucault, también introduce la temática del deseo (de las expectativas, del sentido) en tanto que elemento central de unas relaciones de poder que producen no sólo hábitats sino también habitantes, sujetos inmersos en procesos de subjetivación, en tramas de narrativas y hábitos, como decíamos al inicio, que les preceden y les hacen. Redes de significación que producen lo deseable y que funcionan como mecanismos de atracción tanto para el migrante como para el turista..

Baste afirmar por último, al hilo de esta consideración, y en lo referido a la movilidad turística, que los viajes organizados que comienzan a desarrollarse a mediados del siglo XIX precisaban, antes de realizar el viaje en sí, producir el deseo de viajar (Franklin, 2004) y este elemento, que se perpetúa de formas diversas hasta la actualidad, es clave para entender el éxito del turismo tanto en la forma en que se producen semiótica y materialmente los lugares de destino como en la producción de la subjetividad del turista. Habría una gubernamentalidad del viaje articulada en torno a los lugares que se elijen y la forma en que se visitan, las rutas que se crean, las historias que se cuentan y que, en su entrelazamiento, habrían de posibilitar que el turista consuma en el lugar al que va una "autenticidad escenificada" (MacCannell, 2007), que tenga acceso a lo que supuestamente define ese lugar. Pero todo ello no es sino una construcción que deja en la sombra el lugar no reseñado, la historia no dicha, aquello que no encaja y que habría de distorsionar el "régimen de verdad" que acompaña al espacio turistizado. La gubernamentalidad turística crea así un deseo de viaje, un mecanismo de atracción que moviliza a las personas, con el fin de que pueda ejercitarse tanto un consumo de los espacios de destino inmersos a una producción semiótico-material (con las consecuencias ecológicas -entendidas estas en un sentido amplio-, que ello pudiera tener) como un consumo de los sujetos de otras culturas (con los rescoldos coloniales que esto a menudo conlleva). La domesticación del espacio (el turismo, según Augé, como forma de guerra) y la deshumanización del otro (el turismo étnico, según MacCannell, como forma de racismo) convergen así en un cierto tipo de gubernamentalidad turística subsumida en un hacer y decir transido de lo espectacular.

\section{CONCLUSIÓN}

El hilo conductor que ha recorrido las reflexiones precedentes se articula sobre un triple eje interconectado que alude a la estructura de la movilidad, al ethos domesticar de la modernidad y al modo en que ello se plasma en esas dos figuras paradigmáticas de la movilidad tardomoderna como son el migrante y el turista. El primer eje ahonda en la triada hábitat-hábito-habitante como proceso multidimensional que se recompone en la vivencia de la movilidad y que se ve, igualmente, subsumido en una lógica (no dicotómica sino llena de matices y ambigüedades) que oscila entre la hospitalidadhostilidad; el segundo eje muestra la presencia de un ethos domesticador en la modernidad que es leído desde la importancia del descubrimiento (en tanto que captura de los espacios) y desde la quiebra de las ontologías locales que esa apropiación de los estados desencadena; y, por último, el tercer eje evidencia una arquitectura trenzada en torno a lo neoliberal-neocolonial-securitario como sustrato 
heterogéneo desde el que se configuran, mercantilizándose y espectacularizándose, las movilidades migrantes y turísticas. Un triple eje que se sustenta, asimismo, en la idea de que el sujeto que se desplaza siempre está inmerso en regímenes de movilidad que le preceden y que producen en última instancia el movimiento en unas formas determinadas

Recorrido de trazo grueso puesto que cada eje mencionado requeriría un análisis pormenorizado pero que, sin embargo, reseñando sus elementos más sobresalientes, permite componer una mirada de largo alcance sobre la producción y vivencia de la movilidad. Una mirada crítica que avanza a contracorriente del supuesto carácter positivo inherente a la movilidad (que el imaginario del viaje perpetúa) para mostrar los mimbres de una gubernamentalidad que crea formas de moverse y adjudica, asimismo, posicionamientos diversos en la capacidad para moverse, con lo que aquello que se ensalza en estas "sociedades del movimiento" no es tanto el movimiento en sí mismo cuanto el movimiento que transita por los cauces establecidos, el movimiento codificado, domesticado. Y es, por ello, que la movilidad, la gubernamentalidad que la subyace, requiere un permanente análisis crítico tanto de los imaginarios que encierra cuanto de las prácticas que desencadena, tanto de los espacios que construye como de las subjetividades que produce; un análisis crítico de las violencias simbólicas y materiales que regulan la (in)movilidad pero también, en un análisis ulterior, un desbroce de las posibilidades de articular otras (in)movilidades que se sustraigan a la lógica de la domesticación.

\section{BIBLIOGRAFÍA}

AdAm, B. (1998): Timescapes of modernity, Londres, Routledge.

Agamben, G. (1998): Homo Sacer. El poder soberano y la nuda vida, Valencia, Pre-Textos.

Agamben, G. (2004): Estado de excepción, Valencia, Pre-Textos.

AgIER, M. (2008): On the margins of the world. The refugee experience today, Cambridge, Polity Press.

Bacon, F. [1625] (1980): "Los viajes", en Ensayos, Buenos Aires, Aguilar.

BAUMAN, Z. (2001): “Turistas y vagabundos: héroes y víctimas de la posmodernidad”, en La posmodernidad y sus descontentos, Madrid, Akal.

Bauman, Z. (2006): Modernidad líquida, Buenos Aires, F. C. E.

Benveniste, E. (1983): "La hospitalidad", en Vocabulario de las instituciones europeas, Madrid, Taurus.

BIGO, D. (2008): "Globalized (in)security: the field and the ban-opticon", en Bigo, D. y Tsoukala, A. Terror insecurity and liberty. Iliberal practices of liberal regimes after 9/11, Londres, Rotledge.

Butler, J. (2006): Vida precaria, Buenos Aires, Paidós.

Clifford, J. (1995): "Las culturas del viaje", en Revista de Occidente, núm. 170-171, (pp. 45-73).

Cresswell, T. (2006): On the move. Mobility in the modern western world, Nueva York, Routledge.

Davis, M. (2007): Planeta de ciudades miseria, Madrid, Foca.

Deleuze, G. y Guattari, F. (1988): Mil mesetas, Valencia, Pre-Textos.

Deleuze, G. (1996): "Post-scriptum sobre las sociedades del control", en Deleuze, G. Conversaciones, Valenci, Pre-Textos.

DerridA, J. (2006): La hospitalidad, Buenos Aires, Ediciones de la Flor.

Foucault, M. (1995): La voluntad de saber. Historia de la sexualidad, Madrid, S. XXI.

Foucault, M. (2003): Hay que defender la sociedad, Madrid, Akal.

Foucault, M. (2001): "El sujeto y el poder", en Wallis, B. Arte después de la modernidad. Nuevos planteamientos en torno a la representación, Madrid, Akal.

Foucault, M. (2006): Seguridad, territorio y población, Buenos Aires, F.C.E.

FrankLIN, A. (2004): “Tourism as an ordering: towards a new ontology of tourism”, en Tourist Studies, vol. 4, núm. 3, pp. 277-301.

Harvey, D. (1997): La condición posmoderna, Amorrortu, Buenos Aires.

Harvey, D. (2003): El nuevo imperialismo, Akal, Madrid.

Harvey, D. (2007): Breve historia del neoliberalismo, Akal, Madrid.

KAPlan, C. (1996): Questions of travel, Duke University Press, Londres. 
KAPPler, C. (1986): Monstruos, demonios y maravillas a fines de la Edad Media, Madrid, Akal.

INGOLD, T. (2000): Essays on the perception of the environment: the livehood, dwelling and skill, Londres, Routledge.

Le Breton, D. (1995): Antropología del cuerpo y de la modernidad, Buenos Aires, Nueva Visión.

LefeBvre, H. (1998): The production of space, Oxford, Blackwell.

MacCannell, Dean (2007): Lugares de encuentros vacios, Barcelona, Melusina.

Massey, D. (2005): For space, Londres, Sage.

Mbembe, A. (2003): “Necropolitics”, en Public Culture, núm. 15(1), pp.11-40.

Mendiola, I. (2009): "La bio(tanato)política moderna y la producción de disponibilidad”, en Mendiola, I, (ed.) Rastros y rostros de la modernidad, Barcelona, Anthropos.

Mendiola, I. (2012): "Habitando espacios socionaturales: reflexiones desde la ecología política", en Lopez, D. y Tirado, F.J. Sociología de la composición. Ensayos sobre la teoría del actor-red, Barcelona, Amentia Editorial.

Mignolo, W. (2003): Historias locales/diseños globales. Colonialidad, conocimientos subalternos y pensamiento fronterizo, Madrid, Akal.

Mumford, L. (1994): Técnica y civilización, Madrid, Alianza Universidad.

NANCY, J. L. (2010): Corpus, Madrid, Arena Libros.

PARdo, J. L. (1992): Las formas de la exterioridad, Pre-Textos, Valencia.

PARdo, J. L. (1998): “A cualquier cosa llaman arte (Ensayo sobre la falta de lugares)", en VV. AA, Informe sobre el estado del lugar, Caja de Asturias, Oviedo.

Pimentel, J. (2003): Testigos del mundo. Ciencia, literatura y viajes en la Ilustración, Madrid, Marcial Pons.

PRATT, M. L. (1992): Imperial eyes. Travel writing and transculturation, Nueva York, Routledge.

QuiJano, A. (2005): “Colonialidad del poder, eurocentrismo y América Latina”, en Lander, Edgardo (comp.), La colonialidad del saber: eurocentrismo y ciencias sociales. Perspectivas latinoamericanas, Buenos Aires, CLACSO.

RousseAu, J. J. (1990): Emilio, o de la educación, Madrid, Alianza.

Santos, B. S. (2005): El milenio huérfano. Ensayos para una nueva cultura política, Madrid, Trotta.

SERres, M. (1995): Atlas, Madrid, Cátedra.

SLOTERDIJK, P. (2004): Esferas II Macrosferología, Madrid, Siruela.

Soler, I. (2003): El nudo y la esfera. El navegante como artifice del mundo moderno, Barcelona, El Acantilado.

Stagl, J. (2004): A history of curiosity. The theory of travel 1550-1800, Londres, Routledge.

Urbain, J. D. (1993): El idiota que viaja. Relatos de turistas, Madrid, Endimión.

Van den Abbeele, G. (1992): Travel as metaphor. From Montaigne to Rousseau, Minneapolis, Uninervisity of Minessota Press.

VV.AA (2008): Frontera Sur. Nuevas políticas de gestión y externalización del control de la inmigración en Europa, Barcelona, Virus.

Woolgar, S. (1991): Ciencia: Abriendo la caja negra, Barcelona, Anthropos. 